\title{
Vertical distribution of marine particles and grazers. II. Relation of grazer distribution to food quality and quantity*
}

\author{
J. M. Napp**, E. R. Brooks, P. Matrai, M. M. Mullin \\ Institute of Marine Resources, A-018, Scripps Institution of Oceanography, University of California, San Diego, La Jolla, \\ California 92093, USA
}

\begin{abstract}
Vertical distribution of zooplankton in the Southern California Bight in relation to its food, the microplankton, was examined during a $1 \mathrm{wk}$ cruise when food quality did not vary within the euphotic zone. The vertical distribution of zooplankton biomass was consistently related to the vertical distribution of plant biomass, but only at night. Many of the distributions of individual species were not consistently related to the vertical distribution of plant biomass, primary productivity or phytoplankton growth rate. Of those that were, the majority were related to plant biomass, not primary productivity. Most groups of species which co-occurred in space and time were not homogeneous with respect to either species or developmental state. The daily removal of photosynthetically-produced carbon by the zooplankton was small, but not trivial. Daily water column production of carbon exceeded the community ingestion when calculated using in situ measurements of ingestion and literature values of daily ration. Although many large migratory grazers were situated within the chlorophyll maximum at night, they ingested less carbon than was produced within that feature during the day.
\end{abstract}

\section{INTRODUCTION}

It has been recognized that more consistent patterns exist in the vertical distribution of zooplankton (and other physical and biological properties) than in their horizontal distribution (e.g. Longhurst 1981). These nonrandom vertical patterns result from processes (such as migration) which are relatively stronger vertically than horizontally. The implications are 3-fold: (1) there must be environmental cues associated with the behavior which maintain the pattern; (2) there may be an evolutionary reason for the pattern (cf. Gould \& Lewontin 1978); and (3) the nonrandom vertical distribution of zooplankton (many of which are particlegrazers) may influence the vertical distributions of its food and predators.

\footnotetext{
- Dedicated to the memory of Abraham Fleminger

- Present address: University of Miami, Rosenstiel School of Marine and Atmospheric Science, Division of Biology and Living Resources, 4600 Rickenbacker Causeway, Miami, Florida 33149 , USA
}

The gross details of the vertical distributions of zooplankton generally are agreed upon; the biomass of zooplankton declines rapidly with depth to $1 \mathrm{~km}$ and continues to decline exponentially thereafter (Vinogradov 1970). Also, zooplankton biomass in the euphotic zone tends to be higher at night than by day. However, the fine-scale pattern of zooplankton biomass within the euphotic zone is controversial. In particular, although there is often a sub-surface maximum in biomass of zooplankton, it is controversial whether this maximum is more closely associated with the phytoplankton biomass maximum (Fairbanks et al. 1980, Ortner et al. 1980) or with the phytoplankton productivity or growth maximum which is usually shallower (Longhurst 1976, Herman et al. 1981, Fiedler 1983, Roman et al. 1986). In both cases, food, which is implicitly assumed to limit the growth and reproduction of individual zooplankters, is the hypothesized benefit. Herman et al. (1981), who observed the second pattern, hypothesized that the nutritional quality of the plant cells was greater above the plant biomass maximum than within it. Thus an evolutionary reason for the 
nonrandom distribution of zooplankton was implied; individual zooplankters may enhance their reproductive output by feeding on particles whose nutritional quality is above the average for all available particles (i.e. food quality is more important than sheer bulk).

If zooplankters have fed at the depth at which they are residing when caught and the weight-specific grazing rate of all particle-grazers is the same, then the distribution of grazing pressure is proportional to the distribution of grazer biomass. Thus a subsurface chlorophyll a maximum where plant growth rate is not maximal - a common feature in many oceans (Venrick et al. 1973, Cullen 1982) - may exist, in part, because the central tendency of the depth distribution of grazing pressure is located shallower in the water column (Lorenzen 1967, Herman \& Platt 1983).

Our goal was to document the vertical distribution of zooplankton during a period when the phytoplankton growth rate was maximal above the subsurface phytoplankton biomass maximum so that we could answer 3 important questions: (1) Was there a consistent relation between the vertical distribution of zooplankton and plant biomass, productivity, or phytoplankton growth rate?; (2) Was the food quality greater within the plant biomass maximum or shallower in the water column where the plants are growing faster?; (3) What is the effect of a heterogeneous distribution of grazing pressure on the distribution of plant biomass?

\section{METHODS}

Discrete-depth samples of zooplankton were obtained simultaneously with the samples of particulate matter (Napp et al. 1988 - preceding article). Five zooplankton vertical profiles were from morning pump casts (each from a different day), 3 were from pump casts made around midnight and 1 was from the early evening (Fig. 1). At each of 10 depths sampled, the majority of the water delivered through a $10 \mathrm{~cm}$ (I.D.) plastic hose by the centrifugal pump (Honda, Model WA 30) was filtered through a $53 \mu \mathrm{m}$ Nitex mesh net. During filtration, the nets were placed inside a water bath to minumize net extrusion. The zooplankton retained by the mesh was fixed and preserved in unbuffered formalin $(5 \%)$. Approximately $1.8 \mathrm{~m}^{3}$ of water were filtered for each sample $\left(600 \mathrm{l} \mathrm{min}^{-1}\right.$ for $\left.3 \mathrm{~min}\right)$. The flow rate of the pump was determined every third sample or so by measuring the time required to fill a barrel of known volume. Mullin \& Brooks (1976) using a diaphragm pump (flow rate = $170 \mathrm{lmin}^{-1}$ ) found that only adult Calanus pacificus were undersampled by their pump relative to net-collected organisms. Thus we believe that our much higher flow rates allowed for the quantitative collection of all copepod species and stages.
The zooplankton samples were examined under a dissecting microscope. The 89 categories chosen for enumeration span a wide range of taxonomic levels and include separate developmental stages of the same species. Thus the categories will be referred to as taxa in further discussions. Prior to counting the samples, all sample labels were concealed and the sample order was randomized (Napp 1986).

The total biomass of zooplankton was estimated from measurements of dry weight of the entire preserved sample. Before sieving, each sample was examined under a microscope and large inorganic particles (paint and fiberglass chips) and filamentous detritus were removed. The material retained by a $209 \mu \mathrm{m}$ sieve was washed under a continuous stream of filtered seawater for 5 min using a recirculating water system (Rodriguez \& Mullin 1986). The sample was then transferred to a preweighed filter (Whatman GF/C, $2.4 \mathrm{~cm}$ ), rinsed with filtered seawater, a $6 \%$ ammonium formate solution, then dried to a constant weight $\left(60^{\circ} \mathrm{C}\right.$ for $\left.>16 \mathrm{~h}\right)$. Plant material was a common contaminant of the dry weight samples; however we were unable to assess its contribution to the total dry weight. The dry weight of preserved zooplankton samples has been shown to underestimate the amount of living biomass by 6 to $50 \%$ (Omori 1978, Williams \& Robbins 1982). A correction was not applied to these data because the bias, which was not determined, is a function of the specific composition of the zooplankton and, to a lesser degree, the length of preservation. Thus the conversion factors determined in other studies may not be appropriate here.

It was necessary to find an objective way to determine when the distribution of zooplankton was related to the distribution of another variable, specifically, plant biomass (chlorophyll a), primary productivity, or phytoplankton growth rate. A persistent relationship between zooplankton and another variable was defined according to Mullin \& Brooks (1972) and Mullin et al. (1985) where: (1) the correlation coefficients (Kendall's Tau) between zooplankton and chlorophyll $a$, primary productivity, or phytoplankton growth rate were of the same sign ( + or - ) for all profiles; (2) at least one such correlation coefficient was statistically significant $(p \leq 0.01)$; and (3) the vertical distributions of zooplankton were concordant when ordered according to the distribution of the variable of interest (Kendall's $W, p \leq 0.01$ ). More stringent probability levels were chosen to counter the multiple testing problem (i.e. to reduce the frequency of false rejections of the null hypothesis when one test was used repeatedly on the same data). In a few profiles, 2 (or in one case, 3) samples overlapped in depth. The analyses were performed without combining those nonindependent samples. 
The ratio of primary productivity to chlorophyll a was used as an indirect estimate of phytoplankton growth rate $\left(\mu\right.$, doublings $\mathrm{d}^{-1}$; Cullen \& Eppley 1981). Primary productivity/chlorophyll $a$ and phytoplankton growth rate were correlated (Kendall's Tau $=40, n=33$, $p \leq 0.01$; N.B. primary productivity is used to calculate phytoplankton growth rate therefore one would expect them to be correlated); however, vertical profiles of productivity/chlorophyll a were not concordant when ordered by phytoplankton growth rate indicating the absence of a consistent relationship. Productivity/ chlorophyll a was used in this case because there were more profiles of productivity/chlorophyll a than of phytoplankton growth rate and the variability of replicate particulate carbon measurements resulted in irregular profiles of phytoplankton growth rate.

In situ grazing experiments. Eight feeding experiments were performed (each at 2 different depths except 1) after each pump cast beginning with Cast 8 (Fig. 1). Zooplankton grazing rates were measured, in situ, using a procedure modified from Haney (1971) and Roman \& Rublee (1981). An array of 6 grazing chambers (4 treatments, 1 control, and 1 unlabelled) were towed horizontally $\left(<1 \mathrm{~m} \mathrm{~s}^{-1}\right)$ behind a ship to concentrate the grazers $(209 \mu \mathrm{m}$ mesh internal net; Napp 1986). After 5 min of towing the chambers were closed at depth and a radioactive isotope was introduced $\left({ }^{33} \mathrm{p}\right.$-orthophosphate). Micro-, nano-, and picoplankton take up the isotope at various rates and are grazed by the zooplankton. One hour later, the chambers were brought to the surface, 2 subsamples of the particulate matter within the chamber were collected on $3 \mu \mathrm{m}$ Nuclepore filters, and then the remaining contents of the chamber were passed through a $209 \mu \mathrm{m}$ sieve. The weight-specific grazing rate $\left(G_{i} l\left(\mathrm{mg}\right.\right.$ dry $\left.\mathrm{wt}^{-1} \mathrm{~h}^{-1}\right)$ was calculated from the amount of radioactivity of the particulate matter, the total activity of the zooplankton, the dry weight of the zooplankton (DW) in the chamber and the duration of the experiment (Daro 1978):
$\mathrm{G}=2\left(\mathrm{dpm}\right.$ zooplankton $\left.[\mathrm{dpm} \text { particulate matter }]^{-1}\right)$ $(\text { time })^{-1}(\mathrm{DW})^{-1}$

Community ingestion rates $\left(I_{z}\right)$ were calculated at each depth where the grazing rate had been measured:

$$
\mathrm{I}_{z}=\mathrm{G}_{z} \mathrm{POC}_{z} \mathrm{~B}_{z}
$$

where $\mathrm{G}_{z}=$ weight-specific grazing rate at depth $z_{\text {; }}$ $\mathrm{POC}_{7}=$ concentration of particulate carbon $\left(\mu \mathrm{g} \mathrm{l}{ }^{-1}\right)$ measured at that depth during the preceding pump cast; and $\mathrm{B}_{z}=$ biomass (dry weight $\mathrm{mg} \mathrm{m}^{-3}$ ) of zooplankton $\geq 209 \mu \mathrm{m}$ obtained with the pump. The community ingestion rate will tend to overestimate the true removal of carbon by the grazers if a significant fraction of the carbon retained by the GF/C filters is less than $3 \mu \mathrm{m}$.

The weight-specific grazing rates measured in this study using radioactive isotopes may underestimate the true grazing rate if individual grazers defecate during the experiment (Conover \& Francis 1973, Mullin 1983). The bias is small at first as the animals fill their guts with cells which have low specific activities, and increases during the experiment as the specific activity of the plant cells increases. Thus the bias may be small for our $1 \mathrm{~h}$ experiments.

Community ingestion rate was also estimated (calculated) using the measured zooplankton biomass ( $\geq 209$ $\mu \mathrm{m})$ and literature values for daily ration of copepods, which dominated the zooplankton biomass during the cruise. The zooplankton biomass during a $24 \mathrm{~h}$ period was categorized as consisting of 'small grazers' (diurnal biomass) and 'large migratory grazers' (nocturnal-diurnal biomass). Daily rations used for the calculation were $100 \%$ (Fernandez 1979, Paffenhöfer 1982) and $40 \%$ (Mullin \& Brooks 1970, Vidal 1980, Batchelder 1986) bodily carbon $d^{-1}$, respectively. This estimation method suffers from a number of shortcomings, but is useful for a qualitative comparison with the community ingestion rates calculated from the in situ grazing rates.
Fig. 1. Times and dates of vertical profiles and in situ grazing experiments. Vertical profiles from pump casts are represented by integer numbers, (e.g. Profile $\# 5,=5$ ), grazing experiments by italicized, decimal numbers (e.g. Profile 2, Cast 1 $=2.1)$

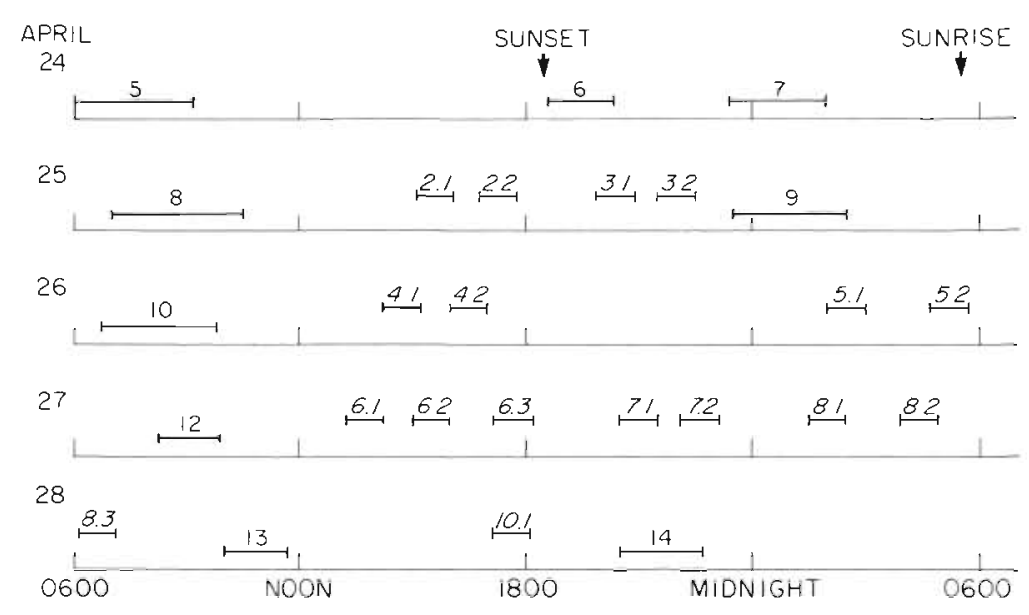



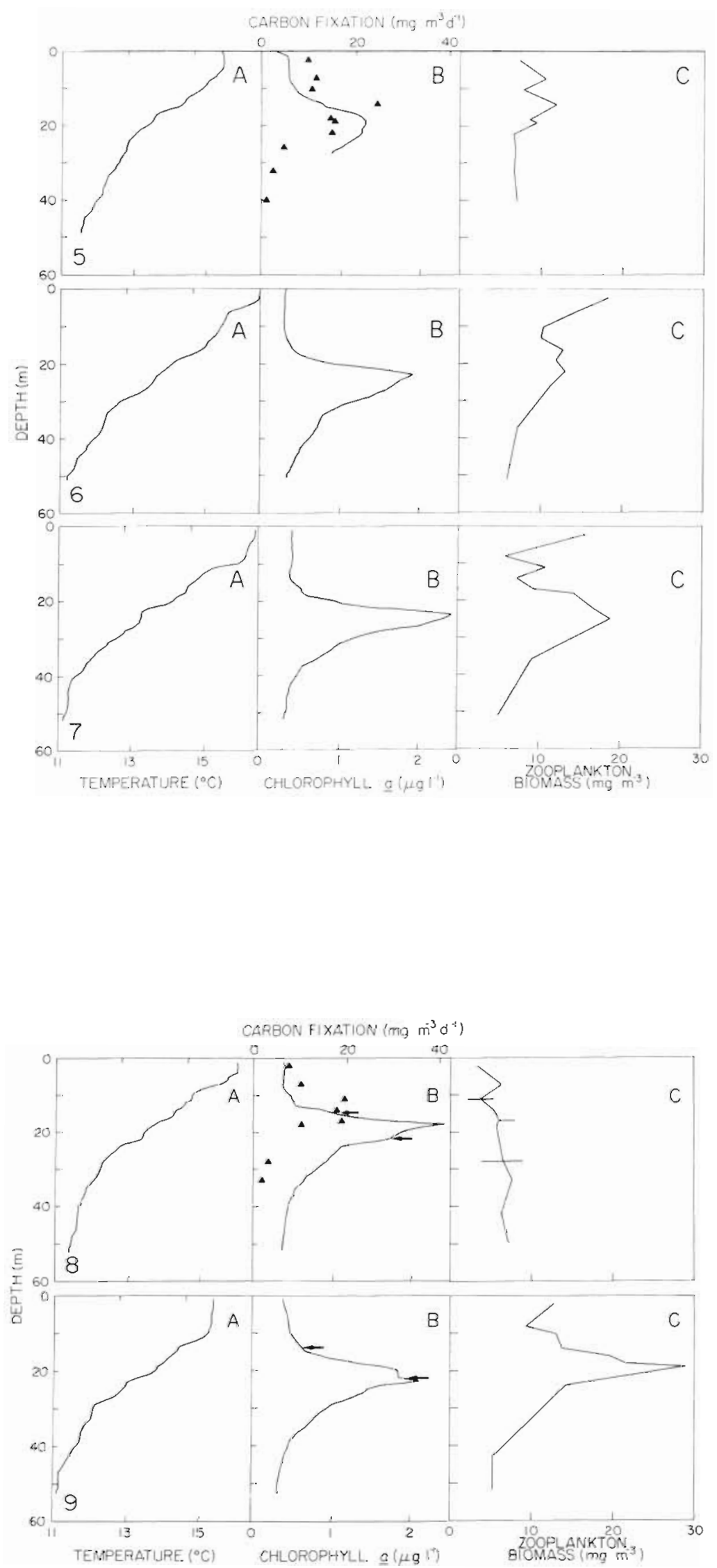

Fig. 2. Profiles 5, 6, and 7. Vertical distributions of (A) temperature $\left({ }^{\circ} \mathrm{C}\right),(\mathrm{B})$ chlorophyll a $\left(\mu \mathrm{g} \mathrm{l}{ }^{-1}\right.$, solid line) and primary productivity ( 4 mg $C$ $\mathrm{m}^{-3} \mathrm{~d}^{-1}$ ), and (C) macrozooplankton biomass $\left(\mathrm{mg} \mathrm{m} \mathrm{m}^{-3}\right)$. Arrows on the chlorophyll-primary productivity plot indicate the location of the in situ grazing experiments. Lines connecting the macrozooplankton biomass data are solely for the reader's convenience and do not signify a continuous distribution

Fig. 3. Profiles 8 and 9. As for Fig. 2. Horizontal lines in (C) indicate the observed range for 3 replicate (consecutive) samples 
Fig. 4. Profiles 10 and 12. As for Fig. 2. In (B): (A) GF/C filters; (O) $3 \mu \mathrm{m}$ Nuclepore filters
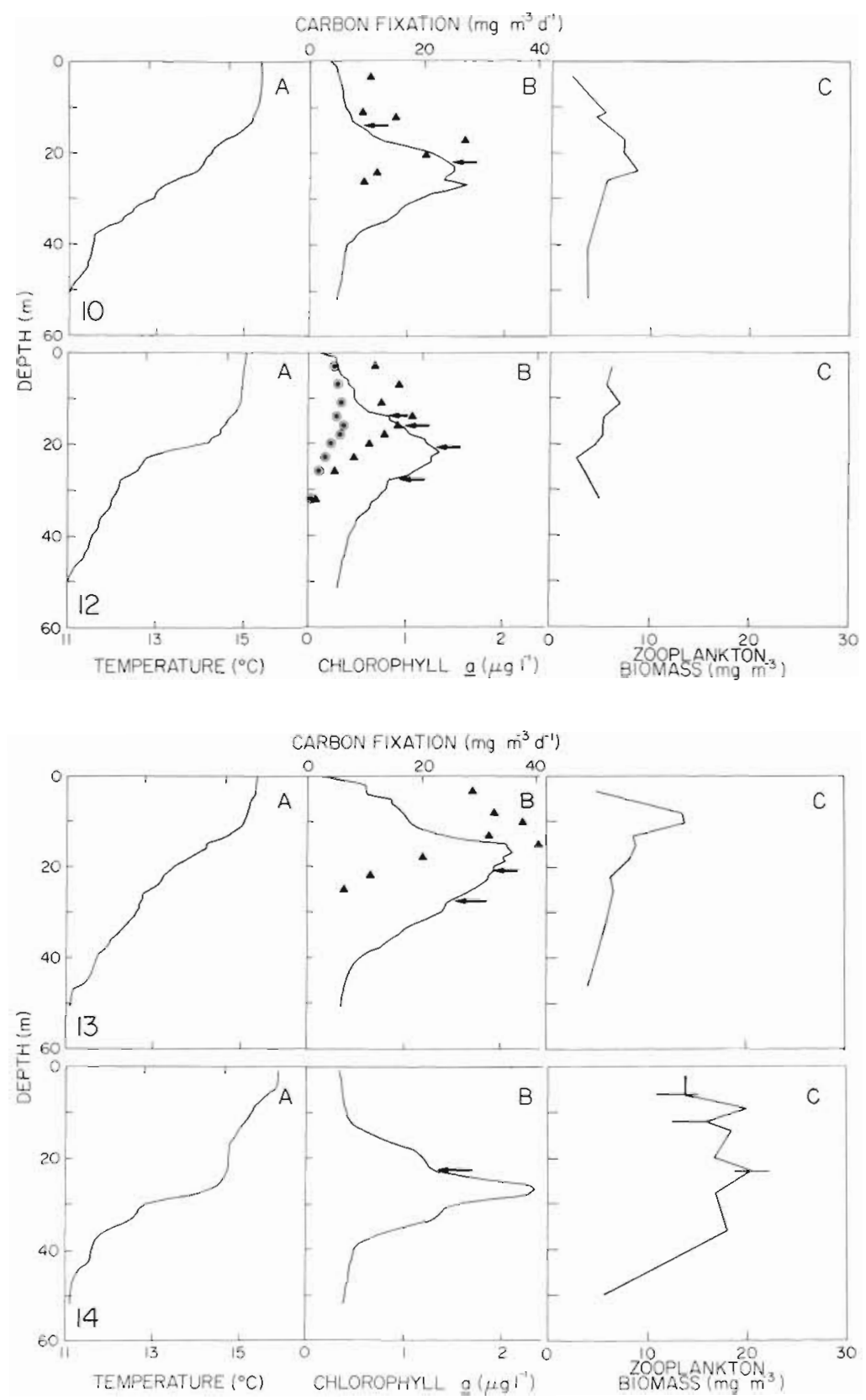

Fig. 5. Profiles 13 and 14. As for Fig. 2. Horizontal lines in $(C)$ indicate the observed range for 3 replicate (consecutive) samples

\section{RESULTS}

\section{Distribution of zooplankton biomass}

Overall, the distribution of total zooplankton biomass did not appear to have a consistent relationship with plant biomass, primary productivity, or productivity/ chlorophyll (Figs. 2 to 5). This impression was confirmed using the objective criterion to define a persistent relationship; the correlation coefficients were not all of the same sign (+ or -) and the rearranged zooplankton profiles were not concordant (Table 1).
The relationship between zooplankton biomass and primary productivity or phytoplankton growth rate could not be determined at night because of the temporal mismatch between the phytoplankton growth rate measurements (initiated each morning after sunrise) and the zooplankton samples obtained early evening or around midnight. There was, however, a persistent relationship between zooplankton biomass and phytoplankton biomass at night. This relationship was significant after the variables depth and temperature were held constant (partial correlation, $p<0.001$ ). Thus the results suggest that food, not hydrostatic pressure or temperature, is the important environmental cue. 
Table 1. Correlation and concordance coefficients between the vertical distributions of zooplankton biomass and chlorophyll a primary productivity, or productivity/chlorophyll. $\mathrm{N}$ : night profiles

\begin{tabular}{|c|c|c|c|c|c|c|c|c|c|}
\hline \multirow[t]{2}{*}{ Kendall's Tau } & \multicolumn{9}{|c|}{ Profile } \\
\hline & 5 & 6 & $7(N)$ & 8 & $9(N)$ & 10 & 12 & 13 & $14(N)$ \\
\hline Chlorophyll a & 0.16 & 0.11 & 0.56 & -0.11 & $0.82^{\circ}$ & $0.73^{\circ}$ & -0.57 & 0.42 & 0.56 \\
\hline Productivity & 0.51 & & & -0.25 & & 0.21 & 0.38 & 0.43 & \\
\hline Productivity/chlorophyll & 0.29 & & & 0.57 & & $-0.71^{\circ}$ & 0.56 & 0.14 & \\
\hline Concordance & \multicolumn{3}{|c|}{ Day \& night } & \multicolumn{3}{|c|}{ Day only } & \multicolumn{3}{|c|}{ Night only } \\
\hline Chlorophyll a & \multicolumn{3}{|c|}{0.18} & \multicolumn{3}{|c|}{0.13} & \multicolumn{3}{|c|}{$0.63^{\circ}$} \\
\hline Productivity & \multicolumn{3}{|c|}{-} & \multicolumn{3}{|c|}{0.20} & \multicolumn{3}{|c|}{-} \\
\hline Productivity/chlorophyll & \multicolumn{3}{|c|}{-} & \multicolumn{3}{|c|}{0.25} & \multicolumn{3}{|c|}{-} \\
\hline
\end{tabular}

Table 2. Behavior of individual taxa sampled. Diel migration, if detected, is reported as either strong (S) or weak (W) and is always toward the surface at night unless otherwise noted $\left({ }^{*} ;\right.$ see text). Taxa whose distributions maintain a persistent relationship to chlorophyll or productivity/chlorophyll are shown indicating whether the relationship is positive $(+)$ or negative $(-)$ during the day and night or is positive, but only during the night $(\mathrm{N})$. The 'Pcal' category consists of individuals from the genera Paracalanus and Clausocalanus

\begin{tabular}{|c|c|c|c|c|c|}
\hline \multirow[t]{2}{*}{ Taxon } & \multirow{2}{*}{$\begin{array}{c}\text { Median } \\
\left(\text { No. } \mathrm{m}^{-3}\right)\end{array}$} & \multirow{2}{*}{$\begin{array}{c}\text { Range } \\
\left(\text { No. }^{-3}\right)\end{array}$} & \multirow{2}{*}{$\begin{array}{c}\text { Diel } \\
\text { migration }\end{array}$} & \multicolumn{2}{|c|}{ Persistent relationships } \\
\hline & & & & Chlorophyll & $\begin{array}{l}\text { Productivity/ } \\
\text { Chlorophyll }\end{array}$ \\
\hline \multicolumn{6}{|l|}{ Calanoid copepods } \\
\hline Calanus pacificus - female & & $0-\quad 23$ & $\mathrm{~S}$ & & \\
\hline Calanus pacificus - male & & $0-$ & $\mathrm{S}$ & & \\
\hline Calanus pacificus - CV & & 12 & w & & \\
\hline Calanus pacificus - CIV & 1 & $0-\quad 32$ & W & $N$ & \\
\hline Calanus pacificus - CIII & 2 & $0-\quad 116$ & & + & - \\
\hline Calanus pacificus - CII & 4 & $0-\quad 222$ & & + & - \\
\hline Calanus pacificus - $\mathrm{CI}$ & 15 & $0-\quad 254$ & & + & - \\
\hline Calanidae + Metridiidae $<$ N3 & 158 & $0-2332$ & $S^{\prime}$ & & \\
\hline Calanidae $>\mathrm{N} 3$ & 136 & $0-7148$ & & & + \\
\hline Calanid unknown - CV & & $0-\quad 2$ & & & \\
\hline Calanid unknown - CIV & & $0-$ & & & \\
\hline Calanid unknown - CIII & & $0-\quad 10$ & & & \\
\hline Calanid unknown - CII & & $0-$ & & & \\
\hline Pleuromamma borealis - female & & 34 & $\mathrm{~S}$ & & \\
\hline Pleuromamma spp. small - male & & $0-$ & S & & \\
\hline Pleuromamma spp. small - CV & & 10 & $\mathrm{~S}$ & & \\
\hline Pleuromamma spp. small - CIV & & $0-$ & & & \\
\hline Pleuromamma abdominalis - female & & $0-$ & $S$ & & \\
\hline Pleuromamma abdominalis - male & & $0-$ & & & \\
\hline Pleuromamma spp. large - female & & $0-$ & & & \\
\hline Pleuromamma spp large - male & & $0-$ & & & \\
\hline Pleuromamma spp large CV & & $0-$ & $\mathrm{S}$ & & \\
\hline Pleuromamma spp large - CIV & & D- & $\mathrm{S}$ & & \\
\hline Metridia lucens - female & & $0-\quad 223$ & $\mathrm{~S}$ & & \\
\hline Metridia lucens - male & & $0-\quad 2$ & & & \\
\hline Metridia lucens - CV & & 32 & $S$ & $N$ & \\
\hline Metridia lucens - CIV. & & 45 & $\mathrm{~S}$ & & \\
\hline Metridiidae copepodites CI-CIII & 1 & $0-\quad 206$ & & & - \\
\hline Metridiidae nauplii. $>$ N3 & 43 & $0-1788$ & & & - \\
\hline Rhincalanus nasutus - female & & $0-\quad 4$ & $s$ & & \\
\hline Rhincalanus nasutus - CIV-CV & & 22 & & & \\
\hline Rhincalanus nasutus - Cl-CIII & & 34 & $\mathrm{~S}$ & $N$ & \\
\hline Rhincalanus nasutus - $\geq \mathrm{N} 3$ & & $0-\quad 236$ & & $\mathrm{~V}$ & \\
\hline Rhincalanus nasutus $-<\mathrm{N} 3$ & & $0-\quad 43$ & & + & \\
\hline
\end{tabular}


Table 2 (continued)

\begin{tabular}{|c|c|c|c|c|c|}
\hline \multirow[t]{2}{*}{ Taxon } & \multirow{2}{*}{$\begin{array}{c}\text { Median } \\
\left(\text { No. } \mathrm{m}^{-3}\right)\end{array}$} & \multirow{2}{*}{$\begin{array}{c}\text { Range } \\
\left(\text { No. } \mathrm{m}^{-3}\right\}\end{array}$} & \multirow{2}{*}{$\begin{array}{c}\text { Diel } \\
\text { migration }\end{array}$} & \multicolumn{2}{|c|}{ Persistent relationships } \\
\hline & & & & Chlorophyll & $\begin{array}{l}\text { Productivity/ } \\
\text { Chlorophyll }\end{array}$ \\
\hline Eucalanus spp. - female & & $0-$ & & + & \\
\hline Eucalanus spp. - CIV-CV & & $0-$ & & & \\
\hline Eucalanus spp. - CI-CrII & & $0-$ & & $N$ & \\
\hline Labidocera trispinosa - female & & $0-$ & & & \\
\hline Labidocera trispinosa - male & & $0-$ & & & \\
\hline Labidocera trispinosa-CV & & $0-$ & & & \\
\hline Labidocera trispinosa - CIV & & $0-$ & & & \\
\hline Labidocera trispinosa-CI-CIII & & $0_{-}$ & & & \\
\hline Labidocera trispinosa $-\geq \mathrm{N} 3$ & & $0-\quad 92$ & $\mathrm{~S}$ & & \\
\hline Labidocera trispinosa $-<\mathrm{N} 3$ & & $0-\quad 78$ & & & \\
\hline Acartia tonsa - temale & 5 & $0-\quad 89$ & & & + \\
\hline Acartia tonsa - male & 4 & $0-\quad 204$ & & & + \\
\hline Acartia spp - CIV-CV & 11 & $0-\quad 509$ & & & + \\
\hline Acartia spp. - CI-CIII & 30 & $0-1362$ & $w^{\cdot}$ & & + \\
\hline Acartiidae nauplij $\geq N 3$ & 352 & $0-2035$ & $\mathrm{~s}$ & & + \\
\hline Acartia danae-female & & $0-\quad 2$ & & & \\
\hline Acartia danae - male & & $0-\quad 1$ & & & + \\
\hline Paracalanus parvus - female & 44 & $0-1351$ & & & \\
\hline Paracalanus parvus CIV-CV & 27 & $0-\quad 775$ & $\mathrm{~S}$ & & \\
\hline Para + Cteno + Clausocalanus - male & 14 & $0-150$ & W & & \\
\hline 'Pcal' copepodites - CI-CIII & 465 & $49-4914$ & & & \\
\hline 'Pcal' nauplii $<$ N3 & 327 & $0-1323$ & & & - \\
\hline 'Pcal' nauplii $\geq N 3$ & 1517 & $0-11806$ & & & - \\
\hline Clausocalanus spp. - female & 4 & $0-\quad 79$ & & & \\
\hline Clausocalanus spp. - CIV-CV & 132 & $0-2123$ & & & \\
\hline Ctenocalanus vanus - female & 7 & $0-\quad 108$ & & + & \\
\hline Ctenocalanus vanus - $\mathrm{CI}-\mathrm{CV}$ & 41 & $0-600$ & & + & \\
\hline Calocalanus pavo - female & 1 & $0-\quad 76$ & & & \\
\hline Calocalanus pavo-CI-CV & 5 & $0-\quad 307$ & & & \\
\hline Calocalanus 'tenuis' - female & & $0-\quad 57$ & & + & \\
\hline Calocalanus 'tenuis' - CI-CV & 5 & $0-\quad 272$ & & + & \\
\hline Calocalanus styleramis - female & & $0-\quad 137$ & & + & \\
\hline Calocalanus styleramis - CI-CV & 4 & $0-\quad 273$ & & & \\
\hline Unspecified predators & & $0-\quad 12$ & $\mathrm{~S}$ & & \\
\hline \multicolumn{6}{|l|}{ Harpacticoid + cyclopoid copepods } \\
\hline Oithona spp. & 1418 & $9-3569$ & & + & \\
\hline Oithona nauplii - small & 3848 & $64-10411$ & & + & \\
\hline Oithona nauplii - large & 959 & $5-4296$ & & $\mathrm{~N}$ & \\
\hline Oncaea spp. & 289 & $0-6236$ & & & - \\
\hline Microsetella spp. & 699 & $5-5705$ & & + & \\
\hline Clytemnestra spp. & & $0-\quad 14$ & & & \\
\hline Corycaees anglicus & 246 & $0-1401$ & & & \\
\hline Euterpina spp. - nauplii & 164 & $0-1896$ & & + & \\
\hline \multicolumn{6}{|l|}{ Other Crustacea } \\
\hline Metanauplii & 2 & 40 & & & \\
\hline Calyptopae & 12 & $0-184$ & W & & - \\
\hline Furcilia & & $0-\quad 8$ & & & \\
\hline Euphausiids (juvenile + adult) & & $0-$ & & & \\
\hline Cladocera (E. nordmanni + E. spinifera) & 3 & $0-\quad 461$ & $\mathrm{~W}^{\bullet}$ & & + \\
\hline \multicolumn{6}{|l|}{ Other } \\
\hline Chaetognatha - large $\geq 4.8$ & 23 & $1-\quad 85$ & & + & \\
\hline Chaetognatha - small $<4.8$ & 54 & $1-\quad 831$ & w & & + \\
\hline Cyphonautes larvae & 5 & $0-\quad 35$ & & + & - \\
\hline Plutei larvae & & $0-\quad 16$ & & + & \\
\hline Medusae & 1 & $0-$ & & & \\
\hline Salps & & $0-$ & & & \\
\hline Appendicularia & 368 & $0-2179$ & & & \\
\hline Foraminifera & 1652 & $0-4052$ & & & + \\
\hline
\end{tabular}




\section{Distribution of individual species}

Also of interest is the behavior of individual taxa and species' developmental stages. Before asking whether the vertical distribution of each taxon was persistently related to plant biomass, primary productivity, or productivity/chlorophyll (phytoplankton growth rate), we examined the temporal (diel) variability of the vertical distribution of each taxon. If the individuals of a particular taxon were more abundant (no. $\mathrm{m}^{-2}$ ) in night profiles than in day profiles (indicating diel vertical migration from below the deepest depth sampled) members of that taxon were considered to be strong vertical migrators (Table 2 ; Kruskal-Wallis Test, $p=$ $0.05)$. If , on the other hand, the depth of the median individual changed from day to night within the depth range sampled, the members of that taxon were considered to be weak vertical migrators (Table 2; KruskalWallis Test, $p=0.05$, Mullin et al. 1985).

The test for diel differences in abundance was unable to make clear distinctions between vertical migration, horizontal patchiness, synchronous molting (i.e. metamorphosis out of the stage being counted) or diel patterns in mortality. For example, Calanidae and Metrididae early nauplii (NI and NII) were found to be much more abundant during the day than at night. Since these young stages are weak swimmers it is improbable that they swam below the deepest depth sampled at night. Two alternate (and more probable) explanations are that these short-lived stages molt in the early evening hours to the third naupliar stage or that there is a diel periodicity to their mortality from predation. Similarly the test indicated that Paracalanus parvus CIV to CV were much more abundant by night than by day. This species has not been reported to be a strong or even weak migrator in previous studies in this region (Mullin et al. 1985)

The question of whether a persistent relationship existed between the vertical distributions of zooplankton and plant biomass, primary productivity, or productivity/chlorophyli was asked for each of the 89 taxonomic categories distinguished in the preserved zooplankton samples. Twenty-three taxa had persistent (positive) relationships with the distribution of chlorophyll, 6 of which were persistent only during the night (Table 2). Two of those 6, Metridia lucens CV and Rhincalanus nasutus CIV to CV, were determined to be strong migrators, and 1 (Calanus pacificus CIV) migrated weakly. Only 1 taxon, small chaetognaths, had a persistent relationship with primary productivity. Chaetognaths feed upon the nauplii and copepodite stages of small copepods, not phytoplankton. Nineteen taxa showed a persistent relationship with productivity/chlorophyll, 9 of which were positive and 10 negative. Thus the vertical distributions of many taxa were not consistently related to any of the 3 variables tested; of those that were, more were positively related to plant biomass than to either primary productivity or productivity/chlorophyll (phytoplankton growth rate).

\section{Composition of species groups}

We also attempted to define 'species groups', that is groups composed of taxa which tended to co-occur with each other in space and time. In the first example, groups were formed by joining those taxa whose relative vertical distributions were similar (Percent Similarity Index, Whittaker 1952; weighted pair-group clustering algorithm, Sokal \& Sneath 1963). Only taxa which (1) are herbivorous or omnivorous (or would soon metamorphose into a feeding stage), (2) were non- or weak migrators, and (3) were common (Fig. 6, Table 3) were used.

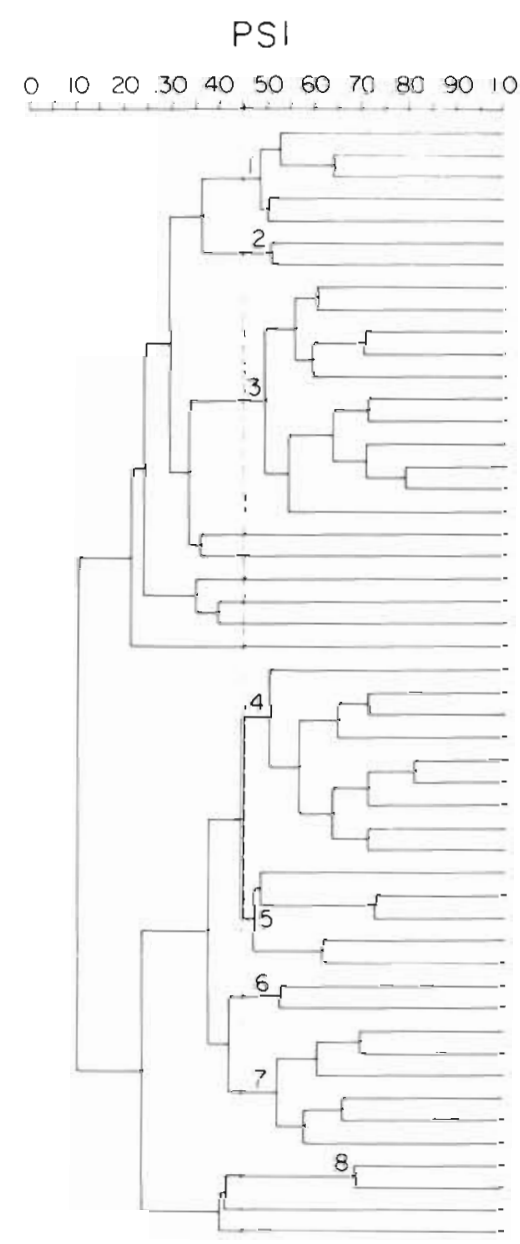

Fig. 6. Dendrogram of similarity (PSI) of the vertical distributions of common, non-migrating, herbivorous and omnivorous zooplankton. Taxa are clustered using the weighted pairgroup method (Sokal \& Sneath 1963). Identity of each taxon is given in Table 3 , in order, from top to bottom 
Table 3. Taxa which co-occur day and night and the range of the depths ( $\mathrm{m}$ ) of the median individual for those profiles. Taxa are listed, in order, as they appear (top to bottom) within each group in Fig. 6 . The 'Pcal' category consists of individuals from the genera Paracalanus and Clausocalanus

$\begin{array}{lr}\text { Group 1 } & \\ \text { C. pacificus CV } & (18-50) \\ \text { C. pacificus CIV } & (18-52) \\ \text { C. vanus female } & (14-46) \\ \text { R. nasutus CI-CIII } & (17-32) \\ \text { Eucalanus spp. CI-CII } & (18-52) \\ \text { Group 2 } & \\ \text { Clausocalanus spp. female } & (16-52) \\ \text { Calyptopae } & (9-33) \\ \text { Group 3 } & \\ \text { C. pacificus CIII } & (18-28) \\ \text { C. pacificus CII } & (17-25) \\ \text { Metridiidae N } \geq 3 & (19-28) \\ \text { Oncaea spp. } & (22-36) \\ \text { Cyphonautes } & (18-28) \\ \text { C. pavo female } & (18-28) \\ \text { C. pavo CI-CV } & (14-28) \\ \text { C. tenuis CI-CV } & (18-28) \\ \text { C. styleramis female } & (14-28) \\ \text { C. styleramis CI-CV } & (14-28) \\ \text { Plutei } & (18-28) \\ \text { Group 4 } & \\ \text { C. pacificus CI } & (10-20) \\ \text { Acartia spp. } \geq \text { N3 } & (8-17) \\ \text { 'Pcal < N3 } & (7-17) \\ \text { Appendicularia } & (10-20) \\ \text { Oithona spp. } & (14-22) \\ \text { Oithona nauplii (small) } & (16-22) \\ \text { Oithona nauplii (large) } & (10-20) \\ \text { Microsetella spp. } & (14-19) \\ \text { Euterpina nauplii } & (14-20) \\ & \end{array}$

\begin{tabular}{|c|c|}
\hline Group 5 & \\
\hline Calanidae + Metridiidae $<\mathrm{N} 3$ & $(7-20)$ \\
\hline A. tonsa female & $(7-16)$ \\
\hline A. tonsa male & $(2-16)$ \\
\hline A. tonsa ClV-CV & $(7-14)$ \\
\hline A. tonsa $\mathrm{Cl}-\mathrm{CIII}$ & $(8-20)$ \\
\hline Group 6 & \\
\hline Calanidae $\geq N 3$ & $(2-14)$ \\
\hline Cladocera & $(2-11)$ \\
\hline Group 7 & \\
\hline P. parvus female & $(2-17)$ \\
\hline Para + Cteno + Clausocalanus & \\
\hline spp. males & $(2-20)$ \\
\hline 'Pcal' CIV-CV & $(2-18)$ \\
\hline 'Pcal' CI-CIIL & $(7-19)$ \\
\hline 'Pcal' $\geq N 3$ & $(6-19)$ \\
\hline Clausocalanus spp. CIV-CV & $(7-17)$ \\
\hline Group 8 & \\
\hline L. trispinosa CIV & $(2-11)$ \\
\hline L. trispinosa CI-CIII & $(2-11)$ \\
\hline Not grouped & \\
\hline R. nasutus $\geq \mathrm{N} 3$ & $(14-20)$ \\
\hline R. nasutus < N3 & $(14-23)$ \\
\hline Metridiidae CI-CIII & $(32-46)$ \\
\hline C. vanus CIV-CV & $(8-32)$ \\
\hline Metanauplii & $(14-42)$ \\
\hline C. tenuis female & $(14-33)$ \\
\hline L. trispinosa $\geq \mathrm{N} 3$ & $(2-17)$ \\
\hline L. trispinosa $<\mathrm{N} 3$ & $(2-18)$ \\
\hline
\end{tabular}

A second grouping was accomplished using the nocturnal vertical distributions of a set of 12 taxa which are herbivorous or omnivorous and were strong or weak vertical migrators (Fig. 7, Table 4). The similarity of the distributions of the first 50 taxa was much greater than that of the second 12 taxa. Note that most groups were not homogeneous with respect to either species or developmental stage.

In summary, the vertical distribution of zooplankton biomass was consistently related to that of plant biomass but only at night. The vertical distributions of only one-third of the taxa examined were consistently related to the vertical distributions of plant biomass, primary productivity or productivity/chlorophyll (phytoplankton growth rate), and the majority of these were positively related to the distribution of plant biomass.

\section{In situ feeding}

In situ grazing experiments were conducted to determine whether the community of grazers removed a large fraction of plant biomass each day; that is, was the production of new plant biomass matched by the removal of plant biomass by the grazers? For this comparison, the average hourly rate was calculated from the measured daily primary productivity (Napp et al. 1988) assuming a constant production rate during the daylight period. An alternative strategy would have been to convert the hourly weight-specific grazing rates to a daily rate. However in this case the temporal feeding pattern of the zooplankton community was not known; therefore it would be difficult to accurately assess a daily grazing rate. When the hourly rates are compared, it is clear that the plants were producing more carbon than the zooplankton grazers ( $\geq 209 \mu \mathrm{m}$ ) could consume (Table 5).

\section{DISCUSSION}

The literature which addresses the zooplankton vertical distribution controversy is difficult to interpret for a variety of reasons. First, the spatial resolution of sam- 


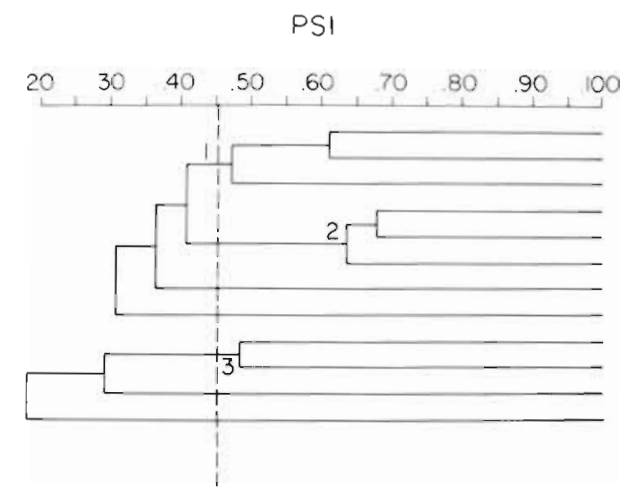

Fig. 7. Dendrogram of similarity (PSI) of the nocturnal vertical distributions of migrating, herbivorous and omnivorous zooplankton. Taxa are clustered using the weighted pair-group method (Sokal \& Sneath 1963). Identity of each taxon is given in Table 4 , in order, from top to bottom

ples differs between studies, ranging from $\pm 1 \mathrm{~m}$ (Herman et al. 1981) to 2 integrated samples in $60 \mathrm{~m}$ of water (Southward \& Barrett 1983). Discrete layers of zooplankton may be as thin as $4 \mathrm{~m}$ (Holliday \& Pieper 1980). Thus some investigators may have seriously undersampled the water column. Second, the initial studies which reported a correspondence between the vertical distributions of phytoplankton and zooplankton biomass did not measure primary production (e.g. Anderson et al. 1972, Mullin \& Brooks 1972); thus they examined only half of the problem. It is also probable that subsequent studies which looked for, but could not confirm, a relationship between the vertical distributions of phytoplankton and zooplankton biomass were not published. Third, confusion has resulted about the location of the hypothesized source of the most nutritious plant cells. If nutritional value is a function of the growth rate of cells (Scott 1980), then the phytoplankton growth rate (and sometimes productivity/ chlorophyll) is a better indicator of nutritional value than primary productivity which is the growth rate weighted by the plant biomass.
To remove some of the uncertainties present in past investigations of the fine-scale vertical distribution of zooplankton we: (1) measured rather than derived primary productivity from a model using spatially averaged physiological rate constants (Fiedler 1983, Herman \& Platt 1983), (2) used not just chlorophyll but several indirect estimates of phytoplankton biomass and checked them for agreement, (3) spaced samples closely together, particularly above the chlorophyll a maximum where the primary productivity maximum usually occurs, (4) compared the particulate matter within and above the plant biomass maximum to test the hypothesis that the particulate matter was indeed different and more nutritious at the primary productivity maximum than within the plant biomass maximum (Napp et al. 1988), and (5) made a point-by-point comparison between the vertical distributions of zooplankton and plant biomass, primary productivity, and phytoplankton growth rate. The statistical analysis emphasized correlation between variables within profiles and concordance between profiles (over time and space). The advantages of this technique relative to visual or statistical comparisons of distribution centroids or maxima is that it uses all the information contained within a profile (cf. Herman et al. 1981, Herman 1983, 1984, Paffenhöfer et al. 1984, Townsend et al. 1984).

Aside from the systematic methodological problems, the patterns of the distribution of particle-grazing zooplankton are inherently variable. The vertical distribution of one species may correspond more closely to primary productivity while the distribution of its congener (which presumably eats the same or similar types of food) can correspond more closely with chlorophyll a (Herman 1983). The same has been observed for different developmental stages of the same species or species groups (Sameoto 1984, Townsend et al. 1984). Finally, seasonal cycles or ontogenetic behaviors may affect the vertical distribution of particle-grazers (Fiedler 1983. Townsend et al. 1984) especially at extreme latitudes (Longhurst et al. 1984)

Table 4. Taxa which co-occur only during the night and the range of the depths (m) of the median individual for those profiles. Taxa are listed, in order, as they appear (top to bottom) within each group in Fig. 7. The 'Pcal' category consists of individuals from the genera Paracalanus and Clausocalanus

Group 1

C. pacificus female

C. pacificus CV

$R$. nasutus CIV-CV

$(19-27)$

$(20-24)$

(19-23)

Group 2

$P$. borealis female

$M$. lucens $\mathrm{CV}$

Pleuromamma spp. (small) CV

$(21-30)$

$(16-31)$
Group 3

C. pacificus CIV (19-25)

Calyptopae

$(10-20)$

Not grouped

$M$. Iucens female $\quad(15-30)$

para + Cteno + Clausocalanus spp.

$(30-39)$

males

Cladocera

$(6-12)$

$(9-11)$ 
Table 5. Proportion of hourly production consumed by grazers. Consumption was calculated from in situ grazing experiments, macrozooplankton biomass and particulate carbon measurements. Daily primary production was estimated from carbon fixation (Napp et al. 1988). Percent carbon production consumed was estimated assuming all carbon production occurred during the $13 \mathrm{~h}$ daylight period (see text)

\begin{tabular}{|c|c|c|c|c|c|c|}
\hline Cast & $\begin{array}{l}\text { Depth } \\
\text { (m) }\end{array}$ & $\begin{array}{l}\text { Consumption } \\
\left(\mu g \mathrm{C}^{-3} \mathrm{~h}^{-1}\right)\end{array}$ & Cast & $\begin{array}{l}\text { Depth } \\
(\mathrm{m})\end{array}$ & $\begin{array}{c}\text { Primary } \\
\text { production } \\
\left(\mathrm{mgCm} \mathrm{m}^{-3} \mathrm{~d}^{-1}\right)\end{array}$ & $\begin{array}{c}\% \text { Production } \\
\text { consumed } \\
\left(\mathrm{h}^{-1}\right)\end{array}$ \\
\hline 2.1 & 22 & 88.6 & \multirow[t]{2}{*}{8} & 18 & 10.0 & 12 \\
\hline 2.2 & 15 & 451.1 & & 14 & 17.4 & 34 \\
\hline 3.1 & 22 & 243.0 & \multirow[t]{2}{*}{9} & 24 & & \\
\hline 3.2 & 14 & 294.5 & & 14 & & \\
\hline 4.1 & 22 & 133.7 & \multirow[t]{2}{*}{10} & 24 & 11.6 & 15 \\
\hline 4.2 & 14 & 468.2 & & 12 & 15.0 & 41 \\
\hline 5.1 & 28 & 93.1 & \multirow[t]{2}{*}{12} & 26 & 4.7 & 26 \\
\hline 5.2 & 16 & 191.8 & & 16 & 15.6 & 16 \\
\hline 6.1 & 14 & 91.1 & \multirow[t]{3}{*}{12} & 14 & 18.2 & 7 \\
\hline 6.2 & 21 & 108.6 & & 20 & 10.7 & 13 \\
\hline 6.3 & 21 & & & & & \\
\hline 7.1 & 16 & 111.7 & \multirow{2}{*}{12} & 16 & 15.6 & 9 \\
\hline 7.2 & 21 & 78.8 & & 20 & 10.7 & 10 \\
\hline 8.1 & 21 & 489.6 & \multirow[t]{3}{*}{13} & 22 & 11.0 & 58 \\
\hline 8.2 & 38 & 236.2 & & 32 & - & - \\
\hline 8.3 & 38 & & & & & \\
\hline 10.1 & 22 & 1111.8 & 14 & 23 & - & - \\
\hline
\end{tabular}

\section{Distribution of zooplankton biomass}

During 'Eumenides III' the diurnal vertical distributions of total zooplankton biomass $(\geq 209 \mu \mathrm{m})$ were independent of the distributions of plant biomass, primary productivity, and productivity/chlorophyll (phytoplankton growth rate). Our observations are contrary to those of another study in the same season and geographical region (Fiedler 1983). During the night, however, the vertical distribution of total biomass was related to that of chlorophyll because many of the large migrants (Calanus pacificus and Metridia lucens females) were concentrated at the chlorophyll a maximum. This is contrary to the observations of Longhurst (1976), Herman et al. (1981), Herman (1983) and Roman et al. (1986) who reported migration past the chlorophyll a maximum. Total zooplankton biomass as reported here included predaceous zooplankton, but not larger, more evasive omnivores (euphausiids) or very small, but numerous particle-grazers (nauplii and protozoa).

The vertical distributions of physical and biological variables are not always independent (e.g. Mullin \& Brooks 1972, Paffenhöfer 1983, Pugh \& Boxshall 1984). This was also true during 'Eumenides III', At night the vertical distribution of zooplankton biomass had a consistent relationship to both depth and plant biomass; however one could statistically distinguish between food and hydrostatic pressure (or temperature) as a potential environmental cue recognized by the zooplankton during our study.

\section{Distribution of individual species}

Many species-specific patterns for particle-grazing zooplankton tended to agree with the vertical distribution of plant biomass both day and night. Contrary to many other reports, only 1 'species' distribution (small chaetognaths) was related to the distribution of primary productivity, and that organism is predaceous, not herbivorous. Nine zooplankton species distributions were consistently related to the vertical distribution of productivity/chlorophyll. The productivity/chlorophyll maximum was generally shallower than the productivity maximum.

\section{Composition of species groups}

Formation of groups of co-occurring species added little insight into the vertical distribution of zooplankton and plant biomass, primary productivity, or productivity/chlorophyll. It did demonstrate, however, that the overall distribution did not consist of thick layers of different development stages, as was observed during 
one season by Townsend et al. (1984). Assemblages of co-occurring particle-grazers were not homogeneous with respect to either species or a common developmental stage among species.

A direct comparison of the groups of co-occurring species recognized here with those presented by Fiedler (1983, his Fig. 4) is difficult because of the different species assemblage present at that time. However, his first group, Clausocalanus furcatus, Paracalanus parvus, and Clausocalanus spp. (CI-CV), roughly corresponds to our Group 7. Notable differences between his observations and ours are that during his spring cruises the vertical distribution of Clausocalanus spp. copepodites was negatively correlated to the distribution of chlorophyll $a$ and the vertical distribution of Calanus pacificus (which was much more abundant then) was strongly correlated with the vertical distribution of derived productivity (compare with Table2). During Fiedler's cruises the population of $C$. pacificus was dominated by late-stage copepodites, while during 'Eumenides III', early-stage copepodites were predominant.

Napp et al. (1988) were unable to refute the simple hypothesis that the plant biomass maximum was the best place for zooplankton to feed. An examination of the types, sizes and nutritional content of cells within the plant biomass maximum and above it, where the phytoplankton growth rates were higher, did not support the hypothesis proposed by Herman et al. (1981) and used subsequently by others to explain their observations. Our observations most closely fit a scenario described by Paffenhöfer et al. (1984) who proposed that when there were large differences between depths in food quantity, but small differences in food quality, most organisms would reside in the plant biomass maximum, and that when the opposite was true, most organisms would be found above the chlorophyll-rich layers where productivity/chlorophyll was greatest.

\section{Primary production, zooplankton grazing, and the} subsurface chlorophyll maximum

The vertical distribution of phytoplankton biomass is the result of many dynamic processes such as production, grazing, sinking and mixing (Riley et al. 1949). Problematic to dynamic models of plant biomass is the description of the vertical distribution of zooplankton biomass and the parameterization of its feeding (functional response curve). Jamart et al. (1977), who used grazing to constrain their model results, apportioned one-half of the zooplankton biomass uniformly with depth while allowing the remainder to vary in direct proportion to the vertical distribution of chlorophyll.
This scheme was suggested by the early results of Anderson et al. (1972), Hobson \& Lorenzen (1972), Mullin \& Brooks (1972), Chester (1975), Youngbluth (1975), and Haury (1976). More recently the scheme has been criticized by those who believe that most of the zooplankton biomass and grazing pressure is situated above the chlorophyll a maximum (Longhurst \& Williams 1979, Herman \& Platt 1983), and that this accounts for the existence of the subsurface chlorophyll maximum.

During 'Eumenides III', the distribution of zooplankton biomass at night was consistently related to the distribution of plant biomass, and the percentage of hourly primary productivity consumed was usually small. The weight-specific grazing rates used to reach this conclusion (although considered high because of plant contamination) are comparable to those measured by Roman et al. (1986). A second way to examine the grazing impact of zooplankton is to use estimates of zooplankton daily rations from the literature, rather than direct measurements of grazing rate as was done here. The conclusion is qualitatively the same using this second method - the estimated daily ration of the zooplankton was less than the measured daily phytoplankton carbon production either within the subsurface chlorophyll maximum or within the entire water column (Table 6). The calculated community ingestion of the zooplankton would be significantly higher if a very large fraction of the biomass was lost during preservation or if the radioisotope method of measuring grazing rates underestimated the grazing rate by the same amount. Several other studies in other regions indicated that zooplankton of a similar size range as found in the present study would ingest a much larger fraction of the daily phytoplankton production (e.g. Herman 1983, Herman \& Platt 1983, Roman et al. 1986). If the system was in steady-state during 'Eumenides III' then a large fraction of the daily production must have been removed from the water column by other grazers (euphausiids, bacteria or protozoa), or by sinking, and mixing. However, during this period and for several weeks thereafter, there was a steady increase in the chlorophyll a concentration of the waters sampled from the Scripps Pier (J. McGowan pers. comm.). To the extent that this is indicative of processes occurring in the Bight as a whole, it suggests that the system was not in a steady state, but that plant biomass was accumulating

Cullen \& Eppley (1981), after describing the subsurface chlorophyll maxima of the Southern California Bight, asked an intriguing question: 'Why don't grazers exploit these layers to the point of depletion?' In this study it appeared that many grazers did exploit these layers at certain times, but these were the largest grazers which have lower weight-specific grazing 
Table 6. Estimated daily ration (carbon demand) of measured zooplankton biomass compared to autotrophic carbon production (A) at the chlorophyll maximum and (B) for the entire water column. Biomass is separated into 'small grazers' (diurnal biomass) and 'large grazers' (nocturnal-diurnal biomass; see text)

\begin{tabular}{|c|c|c|c|c|}
\hline \multirow[t]{2}{*}{ Profiles } & \multicolumn{2}{|c|}{ Zooplankton biomass } & \multirow{2}{*}{$\begin{array}{l}\text { Carbon demand } \\
\left(\mathrm{mgC} \mathrm{m}^{-3} \mathrm{~d}^{-1}\right)\end{array}$} & \multirow{2}{*}{$\begin{array}{l}\text { Primary production } \\
\qquad\left(\mathrm{mgC} \mathrm{m}^{-3} \mathrm{~d}^{-1}\right)\end{array}$} \\
\hline & $\begin{array}{c}\text { Small grazers' } \\
\left(\mathrm{mgC} \mathrm{m}^{-3}\right)\end{array}$ & $\begin{array}{c}\text { 'Large grazers' } \\
\left(\mathrm{mgC} \mathrm{m}^{-3}\right)\end{array}$ & & \\
\hline \multicolumn{5}{|c|}{ A. Chlorophyll maximum } \\
\hline $5 \& 7$ & 2.14 & 3.95 & 3.72 & 4.65 \\
\hline $8 \& 9$ & 1.79 & 7.69 & 4.87 & 10.0 \\
\hline $13 \& 14$ & 2.13 & 3.35 & 3.47 & 6.35 \\
\hline \multicolumn{5}{|c|}{ B. Water column $\left(\mathrm{mgC} \mathrm{m}^{-2}\right)$} \\
\hline $5 \& 7$ & 111. & 84.6 & 145. & 388. \\
\hline $8 \& 9$ & 103. & 108. & 146. & 314. \\
\hline $13 \& 14$ & 115. & 162. & 180. & 668. \\
\hline
\end{tabular}

rates. As a whole, the smaller, more numerous grazers with the highest weight-specific grazing rates did not prefer a single location within the water column. Thus the subsurface phytoplankton biomass maximum we observed persisted, in part, because the total biomass of grazers was low and because those grazers with the highest weight-specific grazing rates were not concentrated there even though the layer was nutritionally advantageous.

Acknowledgements. We gratefully acknowledge the hard work of P. Andrews, M. Lenihan, J. Nelson, J. Schmitt, M. Van Nostrand, W. Wakefield, and the captain and crew of the RV 'Robert Gordon Sproul'. Major equipment loans from R. Eppley, L. Haury, and the Marine Ecological Consultants, (Encinitas, Calif., USA) facilitated our sampling. We also thank E. Stewart, who was responsible for computer processing of the data collected, and M. Gordon, M. Greene, B. Hardie, C. Lundy and D. Osborn who typed our manuscript. The manuscript has benefited from criticisms offered by Wm. Balch, R. Eppley, J. McGowan, J. Nelson, R. Olshen, P. Ortner, R. Pinkel, M. Roman, S. Shapiro, and 3 anonymous reviewers. This project was funded by NSF Grant, OCE 83-15190, to M. Mullin.

\section{LITERATURE CITED}

Anderson, G. C., Frost, B. W., Peterson, W. K. (1972). On the vertical distribution of zooplankton in relation to chlorophyll concentration. In: Takenouti, A. Y (ed.) Biological oceanography of the northern North Pacific Ocean. Idemitsu Shoten, Tokyo, p. 341-345

Batchelder, H. P. (1986). Phytoplankton balance in the oceanic subaractic Pacific: grazing impact of Metridia pacifica. Mar. Ecol. Prog. Ser. 34: 213-225

Chester, A. J. (1975). Ciliate microzooplankton distribution relative to a subsurface chlorophyll maximum layer off the Washington coast. M. Sc. report, University of Washington, Seattle

Conover, R. J., Francis, V. (1973). The use of radioactive isotopes to measure the transfer of materials in aquatic food chains. Mar. Biol. 18: 272-283

Cullen, J. J. (1982). The deep chlorophyll maximum: compar- ing vertical profiles of chlorophyll a. Can. J. Fish. Aquat. Sci. 39: 791-803

Cullen, J. J., Eppley, R. W. (1981). Chlorophyll maximum layers of the Southern California Bight and possible mechanisms of their formation and maintenance. Oceanologica Acta 4: 23-32

Daro, M. H. (1978). A simplified ${ }^{14} \mathrm{C}$ method for grazing measurements on natural planktonic populations. Helgoländer wiss. Meeresunters. 31. 241-248

Fairbanks, R. S., Wiebe, P. H., Be, A. W. H. (1980). Vertical distribution and isotopic composition of living planktonic foraminifera in the western North Atlantic. Science 207. $61-63$

Fernandez, F. (1979). Nutritional studies in the nauplius larva of Calanus pacificus (Copepoda: Calanoida). Mar. Biol. 53: $131-147$

Fiedler, P. C. (1983). Fine-scale spatial patterns in the coastal epiplankton off southern California. J. Plankton Res. 5: 865-879

Gould, S. J., Lewontin, R. C. (1978). The spandrels of San Marco and the Panglossian paradigm: a critique of the adaptationist programme. Proc. R. Soc. London 205: $581-598$

Haney, J. F. (1971). An in situ method for the measurement of zooplankton grazing rates. Limnol. Oceanogr 16: 970-977

Haury, L. R. (1976). Small-scale pattern of a California Current zooplankton assemblage. Mar. Biol. 37: 137-157

Herman, A. W. (1983). Vertical distribution patterns of copepods, chlorophyll, and production in the northeastern Baffin Bay. Limnol. Oceanogr 28: 709-719

Herman, A. W. (1984). Vertical copepod aggregations and interactions with chlorophyll and production on the Peru Shelf. Cont. Shelf Res. 3: 131-146

Herman, A. W., Platt, T. (1983). Numerical modelling of diel carbon production and zooplankton grazing on the Scotian Shelf based on observational data. Ecol. Modelling 18: $55-72$

Herman, A. W., Sameoto, D. D., Longhurst, A. R. (1981). Vertical and horizontal distribution patterns of copepods near the shelf break south of Nova Scotia. Can. J. Fish. Aquat. Sci. 38: 1065-1076

Hobson, L. A., Lorenzen, C. J. (1972). Relationship of chlorophyll maxima to density structure in the Atlantic Ocean and Gulf of Mexico. Deep Sea Res. 19A: 297-306

Holliday, D. V., Pieper, R. E. (1980). Volume scattering strengths and zooplankton distributions at acoustic frequencies between 5 and $3 \mathrm{MHz}$. J. Acoust. Soc. Am. 67: 135-146 
Jamart, B. M., Winter, D. F., Banse, K., Anderson, G. C., Lam, R. K. (1977). A theoretical study of phytoplankton growth and nutrient distribution in the Pacific Ocean off the northwestern U.S. coast. Deep Sea Res. 24A: 753-773

Longhurst, A. R. (1976). Interactions between zooplankton and phytoplankton profiles in the eastern tropical Pacific Ocean. Deep Sea Res. 23A: 729-754

Longhurst, A. R. (1981). The significance of spatial variability. In: Longhurst, A. R. (ed.) Analysis of marine ecosystems. Academic Press, New York, p. 415-442

Longhurst, A. R., Williams, R. (1979). Materials for plankton modelling: vertical distribution of Atlantic zooplankton in summer. J. Plankton Res. 1: 1-28

Longhurst, A. R., Sameoto, D., Herman, A. (1984). Vertical distribution of arctic zooplankton in summer: eastern Canadian archipelago. J. Plankton Res. 6: 137-168

Lorenzen, C. J. (1967). Vertical distribution of chlorophyll and phaeopigments. Baja, California. Deep Sea Res. 14A: $735-746$

Mullin, M. M. (1983). In situ measurement of filtering rates of the salp Thalia democratica, on phytoplankton and bacteria. J. Plankton Res. 5: 279-288

Mullin, M. M., Brooks, E. R. (1970). Growth and metabolism of two planktonic, marine copepods as influenced by temperature and type of food. In: Steele, J. H. (ed.) Marine food chains. Oliver and Boyd, Edinburgh, p. 74-95

Mullin, M. M., Brooks, E. R. (1972). The vertical distribution of juvenile Calanus (Copepoda) and phytoplankton within the upper $50 \mathrm{~m}$ of water off La Jolla, California. In: Takenouti, A. Y. (ed.) Biological oceanography of the northern North Pacific Ocean. Idemitsu Shoten, Tokyo, p. 347-354

Mullin, M. M. Brooks, E. R. (1976). Some consequences of distributional heterogeneity of phytoplankton and zooplankton. Limnol. Oceanogr 21: 784-796

Mullin, M. M., Brooks, E. R., Reid, F. M. H., Napp, J., Stewart, E. F. (1985). Vertical structure of nearshore plankton off Southern California: a storm and larval fish food web. Fish Bull U.S. 83: 151-170

Napp, J. M. (1986). The vertical distribution and in situ feeding of marine particle-grazers in relation to their food, the microplankton. Ph. D. dissertation, University of California, San Diego

Napp, J. M., Brooks, E. R., Reid, F. M. H., Matrai, P., Mullin M. M. (1988). Vertical distribution of marine particles and grazers. I. Vertical distribution of food quality and quantity. Mar Ecol. Prog. Ser 50: 45-58

Omori, M. (1978). Some factors affecting on dry weight, organic weight and concentrations of carbon and nitrogen in freshly prepared and in preserved zooplankton. Int. Revue ges. Hydrobiol. 63: 261-269

Ortner, P. B., Wiebe, P. H., Cox, J. L. (1980). Relationship between oceanic epizooplankton distributions and the seasonal deep chlorophyll maximum in the northwestern Atlantic Ocean. J. mar. Res. 38: 507-531

Paffenhöfer, G.-A. (1982). Grazing by copepods in the Peru upwelling. Deep Sea Res. 29: 145-147

Paffenhöfer, G.-A. (1983). Vertical zooplankton distribution on the northeastern Florida shelf and its relation to temperature and food abundance. J. Plankton Res. 5: 15-33

Paffenhöfer, G.-A., Wester, B. T., Nicholas, W. D. (1984). Zooplankton abundance in relation to state and type of intrusions onto the southeastern United States shelf during summer. J. mar. Res. 42: 995-1017

Pugh, P. R., Boxshall, G. A. (1984). The small-scale distribution of plankton at a shelf station off the northwest African coast. Cont. Shelf Res. 3: 399-424

Riley, G. A., Stommel, H., Bumpus, D. F. (1949). Quantitative ecology of the plankton of the western North Atlantic. Bull. Bingham oceanogr. Coll. 12: 1-169

Rodriguez, J., Mullin, M. M. (1986). Diel and interannual variation of size-distribution of oceanic zooplankton biomass. Ecology 67: 215-222

Roman, M. R., Rublee, P. A. (1981). A method to determine in situ zooplankton grazing rates on natural particle assemblages. Mar. Biol. 65: 303-309

Roman, M. R., Yentsch, C. S., Gauzens, A. L., Phinney, D. A. (1986). Grazer control of the fine-scale distribution of phytoplankton in warm-core Gulf Stream Rings. J. mar. Res. 44: 795-813

Sameoto, D. D. (1984). Vertical distribution of zooplankton biomass and species in Northeastern Baffin Bay related to temperature and salinity. Polar Biol. 2: 213-224

Scott, J. M. (1980). Effect of growth rate of the food alga on the growth/ingestion efficiency of a marine herbivore. J. mar. biol. Ass. U.K. 60: 681-702

Sokal, R. R., Sneath, P. H. A. (1963). Principles of numerical taxonomy. W. H. Freeman and Co.

Southward, A. J., Barrett, R. L. (1983). Observations on the vertical distribution of zooplankton, including post-larval teleosts, off Plymouth in the presence of a thermocline and a chlorophyll-dense layer. J. Plankton Res. 5: 599-618

Townsend, D. W., Cucci, T L., Berman, T (1984). Surface chlorophyll maxima and vertical distribution of zooplankton in the Gulf of Maine. J. Plankton Res. 6: 793-802

Vidal, J. (1980). Physioecology of zooplankton. IV Effects of phytoplankton concentration, temperature, and body size on the net production efficiency of Calanus pacificus. Mar, Biol. 56: 203-211

Vinogradov, M. E. (1970). Vertical distribution oceanic zooplankton. Akad. Nauk SSR. Transl. by Israel Program Sci. Transl. TT69-59015

Venrick, E. L., McGowan, J. A., Mantyla, A. W. (1973). Deep maxima of photosynthetic chlorophyll in the Pacific Ocean. Fish. Bull. U.S. 71: 41-52

Whittaker, R. H. (1952). A study of summer foliage insect communities in the Great Smokey Mountains. Ecol. Monogr. 22: 1-44

Williams, R., Robbins, D. B. (1982). Effects of preservation on wet weight, dry weight, nitrogen and carbon contents of Calanus helqolandicus (Crustacea: Copepoda). Mar. Biol. 71. 271-281

Youngbluth, M. J. (1975). The vertical distribution and diel migration of euphausiids in the central waters of the eastern South Pacific. Deep Sea Res. 22A: 519-536 